\title{
Annual variations of soil erodibility of silt loam developed from loess based on 10-years runoff plot studies
}

\author{
JERZY REJMAN, RYSZARD BRODOWSKI, IWONA IGLIK \\ Institute of Agrophysics, Polish Academy of Sciences, Lublin
}

\begin{abstract}
Annual variations of soil erodibility of silt loam developed from loess based on 10-years runoff plot studies. Results of 10-years runoff plot experiments carried out on two sites of the Lublin Upland were presented. Despite similar soils and climatic conditions, studies showed large differences in annual soil erodibility ( $\mathrm{K}$ factor of the USLE) between both sites. Experimentally derived values of the factor were dependent on tillage direction and time of maintaining runoff-plots in fallow conditions. On a site cultivated in contour direction, 4-year period was insufficient to achieve $\mathrm{K}$ values similar to the predicted values from the USLE. In contrast to this, on a site cultivated up-down slope, similar experimental and predicted $\mathrm{K}$ values were obtained after 2 years and remained at the same level during next 4 years. Results enabled to identify limitations of the USLE application for erosion prediction in Poland. Studies proved that soil erodibility could be used for prediction of erosion risk for silt loam developed from loess. However, application of soil erodibility approach to the event-base models is questionable for variation of $\mathrm{K}$ factor in the initial years. As far, the factors affecting soil erodibility changes are not recognized and need further research.
\end{abstract}

Key words: soil erodibility, USLE, erosion prediction, silt loam.

\section{INTRODUCTION}

Soil erodibility was developed in the USLE (Universal Soil Loss Equation) technology to evaluate soil reaction to joining action of rainfall and runoff
(Wischmeier and Smith 1978). Originally the term was expressed as a ratio of soil losses from standard runoff-plot to rainfall and runoff erosivity factor, being a product of total kinetic rainfall energy and its maximal intensity during 30 minutes. Based upon multi-years experiments conducted in the middle-east part of the USA, a multi-regression equation was developed to quantify soil erodibility from basic soil information (texture, organic matter, structure and profile permeability). Despite some uncertainties of transfer of empirical relations to other soil-climatic conditions, soil erodibility values assessed from the equation becomes one of the main components of many models aimed to predict areas of erosion risk at large scale (Van Rompaey et al. 2003; Kirkby et al. 2004). Attempts of introduction of the USLE technology were undertaken also in Poland (Banasik and Górski 1993; Koreleski 1994; Niemiec 1998; Klima 2002; Licznar 2005). However, they have not resulted in development of risk assessment maps of water erosion, which are still based on cross-factor analysis and are deprived of quantitative information of soil losses (Wawer and Nowocień 2007). Such information provides maps 
generated by international teams. Although various models are used, majority of them relies on the USLE approach. It is assessed that for the most endanger by water erosion regions of Poland, soil losses could reach up to $20 \mathrm{Mg} \cdot \mathrm{ha}^{-1}$ (Van Rompaey et al. 2003). Such evaluation needs verification by field studies. Till now, relatively short time of runoff-plots experiments and rather low rainfall erosivity suggested poor applicability of the USLE for Poland (Rejman et al. 1998; Rejman et al. 1999; Stasik and Szafrański 2001).

The aim of the studies is determination of soil erodibility and its comparison with predicted values from the USLE for soils developed from loess on the basis of 10 -year studies on runoff plots.

\section{MATERIALS AND METHODS}

Studies were conducted on two sites of the Lublin Upland, Czesławice (1992-1995) and Bogucin (1997-2007), located at the distance of $10 \mathrm{~km}$ from each other. Sites are covered by deep loess deposit form which silt loam was developed. Characteristics of soils are presented in Table 1. According to classification of Turski et al. (1987), soils are ranked as slightly eroded. The slopes of both sites varied by physiographic features and direction of tillage. Plots in Czesławice were located on $8 \%$ slopes of southern exposure whilst in Bogucin - on $12 \%$ slope of northern exposition.
On the former site, plow was performed in contour direction, on the latter up-and down slope. In both sites, runoff-plots were $3 \mathrm{~m}$ width and $20 \mathrm{~m}$ long. Immediately after plowing, plots were harrowed to provide a smooth uniform surface and plastic borders were driven about $10 \mathrm{~cm}$ into soil to define a runoff collection area. The plots were maintained in a bare conditions by herbicide treatment, and additionally, 2-3 operation with a hoe and a rake were provided each season to destroy soil seal. At the lower parts of the plots, runoff collection installations were established. After each period of rainfall, the amount of collected runoff and soil was measured. For Czesławice site, plots were established in the summer 1992, and first measurements were started in the autumn 1992, and ended in August 1995. For Bogucin, plots were established in the autumn 1996, and measurements were started in the spring 1997. Registration of erosion on this site on plots maintained in fallow was carried in the years 1997-2000, and 2004, 2007. In the meantime $(2002,2003)$ plots were planted with spring barley and sugar beets (without organic manure), and in the years 2005-2006 remained as fallow without monitoring of erosion. Measurements were carried on singular runoff plots. In the period 1997-1998 erosion was monitored on two bare plots, and the differences between soil losses from both plots were up to $20 \%$. For each measurement period, rain and runoff erosivity

TABLE 1. Some properties of studied soils

\begin{tabular}{|l|c|c|c|c|c|c|c|c|}
\hline \multirow{2}{*}{ Site } & \multicolumn{6}{|c|}{ Percentage of particle size fractions $(\mathrm{mm})$} & $\mathrm{OM}$ & \multirow{2}{*}{$\mathrm{pH}_{\mathrm{KCl}}$} \\
\cline { 2 - 9 } & $1-0.1$ & $0.1-0.05$ & $0.05-0.02$ & $0.02-0.005$ & $0.005-0.002$ & $<0.002$ & $\%$ & \\
\hline Czesławice & 1.0 & 19.0 & 46.0 & 17.0 & 5.0 & 12.0 & 1.71 & 5.2 \\
\hline Bogucin & 0.7 & 12.3 & 43.0 & 25.0 & 7.0 & 12.0 & 1.68 & 6.4 \\
\hline
\end{tabular}


factor $\mathrm{EI}_{30}$ (Wischmeier and Smith 1978) was caluclated from rainfall intensity records obtained from raingauge placed near the plots (Bogucin) or from meteorological station of Czesławice (Lublin Agricultural University), located $500 \mathrm{~m}$ from plots.

Based on measured annual soil losses and erosivity factor, soil erodiblity was determined and compared with the values obtained from the nomograph (Wischemier and Smith 1978) and the following equation (Renard et al. 1997):

$$
\begin{aligned}
& K=\left[2.1 \cdot 10^{-4} \cdot(12-O M) \cdot M^{1.14}+\right. \\
& +3.25 \cdot(s-2)+2.5 \cdot(\mathrm{p}-3)] / 100
\end{aligned}
$$

where:

$M$ - particle-size parameter, $\left(m_{\text {silt }}+m_{v f s}\right)$. $\cdot\left(100-m_{\text {clay }}\right)$ where $m_{\text {silt }}$ is the \% of silt $(0.002-0.05 \mathrm{~mm}$ diameter particles, $m_{v f s}$ is the percent of very fine sand $(0.05-0.10 \mathrm{~mm}$ diameter particles), and $m_{\text {clay }}$ is the percent clay content $(<0.002 \mathrm{~mm})$,

$O M$ - organic matter (\%), $s-$ soil structural class ( 2 - fine granular), $p$ - profile permeability class $(4-$ slow to moderate: $\left.5-15 \mathrm{~mm} \cdot \mathrm{h}^{-1}\right)$.

\section{RESULTS AND DISCUSSION}

\section{Rainfall characteristics}

Precipitation characteristics are presented in Table 2. Annual mean precipitation was $572.7 \mathrm{~mm}$ (with standard deviation of 73.2), and erosivity index $\mathrm{EI}_{30}-1164.2$ MJ.ha. $\mathrm{mm}^{-1} \cdot \mathrm{mm}^{-1}(468.1)$. For the period 1992-1995, both mean annual precipitation $(569.0 \mathrm{~mm})$ and erosivity index $\left(1090.2 \mathrm{MJ} \cdot h \mathrm{ha} \cdot \mathrm{mm}^{-1} \cdot \mathrm{mm}^{-1}\right)$ were slightly smaller in comparison to those for the years 1997-2007 (respectively, 575.2 and 1213.5). To wet years belonged 1999 and 1997, whilst especially low precipitation was recorded in 1993. Erosivity index showed large annual variation being resulted from the presence or absence of intensive rainfalls. According to the values of $\mathrm{EI}_{30}$ index, the most favorable conditions for erosion were in the years 1999, 1995 and 2007, whilst the least - 1993, 2000 and 2004. During measurement periods, 4 intensive events took

\begin{tabular}{|c|c|c|c|c|c|c|c|c|c|c|}
\hline \multirow{3}{*}{ Year } & \multicolumn{2}{|c|}{ Annual } & \multicolumn{8}{|c|}{ Precipitation in runoff measurement periods } \\
\hline & \multirow{2}{*}{\begin{tabular}{|c|}
$\begin{array}{c}\text { Precipi- } \\
\text { tation }\end{array}$ \\
$(\mathrm{mm})$ \\
\end{tabular}} & \multirow{2}{*}{$\begin{array}{c}\begin{array}{c}\mathrm{EI}_{30} \\
\text { index }\end{array} \\
(\mathrm{MJ} \cdot \mathrm{mm} \cdot \\
\left.\cdot \mathrm{ha}^{-1} \cdot \mathrm{h}^{-1}\right)\end{array}$} & \multirow{2}{*}{$\begin{array}{c}\begin{array}{c}\text { Total } \\
\text { Rainfall }\end{array} \\
(\mathrm{mm})\end{array}$} & \multirow{2}{*}{\begin{tabular}{|c|}
$\begin{array}{c}\text { Rainfall } \\
>12.7 \mathrm{~mm}\end{array}$ \\
$(\mathrm{~mm})$
\end{tabular}} & \multirow[t]{2}{*}{$\begin{array}{l}\% \text { of } \\
\text { total }\end{array}$} & \multirow{2}{*}{$\begin{array}{c}\begin{array}{c}\mathrm{EI}_{30} \\
\text { index }\end{array} \\
(\mathrm{MJ} \cdot \mathrm{mm} \cdot \\
\left.\cdot \mathrm{ha}^{-1} \cdot \mathrm{h}^{-1}\right)\end{array}$} & \multicolumn{4}{|c|}{$\begin{array}{l}\text { No of events at various range } \\
\text { of } \mathrm{EI}_{30}\left(\mathrm{MJ} \cdot \mathrm{mm} \cdot \mathrm{ha}^{-1} \cdot \mathrm{h}^{-1}\right)\end{array}$} \\
\hline & & & & & & & $0-50$ & $50-100$ & $100-400$ & $>400$ \\
\hline 1992 & 606 & 1003.6 & 168.6 & 101.5 & 60.2 & 526.3 & 3 & 0 & 0 & 1 \\
\hline 1993 & 457 & 593.5 & 292.2 & 111.8 & 38.3 & 312.6 & 4 & 2 & 0 & 0 \\
\hline 1994 & 667 & 946.4 & 217.0 & 93.2 & 42.9 & 892.7 & 1 & 0 & 2 & 1 \\
\hline 1995 & 546 & 1817.5 & 195.5 & 98.2 & 50.2 & 662.4 & 1 & 2 & 2 & 0 \\
\hline 1997 & 508 & 1166.1 & 288.4 & 178.7 & 62.0 & 975.2 & 3 & 4 & 1 & 1 \\
\hline 1998 & 583 & 1122.6 & 329.3 & 274.4 & 83.3 & 947.7 & 7 & 3 & 3 & 0 \\
\hline 1999 & 698 & 1853.3 & 231.3 & 180.5 & 78.0 & 1181.0 & 4 & 0 & 4 & 0 \\
\hline 2000 & 598 & 711.3 & 206.9 & 183.5 & 88.7 & 364.8 & 5 & 1 & 1 & 0 \\
\hline 2004 & 542 & 734.7 & 78.0 & 71.2 & 91.3 & 347.4 & 4 & 0 & 1 & 0 \\
\hline 2007 & 522 & 1693.3 & 270.4 & 193.8 & 71.7 & 1408.2 & 6 & 4 & 1 & 1 \\
\hline
\end{tabular}

TABLE 2. Some characteristics of precipitation 
place: 07.10.1992 (50 mm, 315 minutes, 485.6 MJ.ha. $\left.\mathrm{mm}^{-1} \cdot \mathrm{mm}^{-1}\right), \quad 09.08 .1994$ (34.9; 140; 595.5), 06.09.1997 (33.0; $40 ; 506.5)$ and 22.05 .2007 (47.4; 110; 898.17). In comparison to the previously published data (Rejman 2002), a corrected value was introduced to the rainfall of 09.06.1998, which was estimated initially on $690 \mathrm{MJ} \cdot \mathrm{ha} \cdot \mathrm{mm}^{-1} \cdot \mathrm{mm}^{-1}$. Taking into account that this event consisted of series of short storms (interrupted by 10-20 minutes pauses), its corrected value should be lower and equals 295.5 erosivity units. To better understand the $\mathrm{EI}_{30}$ approach in description of rainfall events it worth to add that typical short intensive summer rain of $30 \mathrm{~mm}$ during 20 and 30 minutes responds to 209 and 503 units of erosivity, respectively.

\section{Soil losses and erodibility}

In the years 1992-2007, erosion on runoff plots was measured during 83 periods ( 33 - in Czesławice and 50 - in Bogucin). Total soil losses in reference to the area of 1 ha were $19.03 \mathrm{Mg}$ (Czesławice) and 268.59 Mg (Bogucin). Majority of erosion derived from April to October, and soil losses from snowmelt were $13 \%$ and
$1.5 \%$ of the total amount, respectively for Czesławice and Bogucin. Whilst erosion from snowmelt was not always collected for the latter site, further analysis were limited to the period April-October (25 cases for Czesławice, and 47 for Bogucin). It should be pointed that sometimes measurement period ended earlier than in October, i.e. in 2004 measurements were stopped after devastation of plots by rill formation due to rainfall of 28.07.2004. To compare erosion on both sites and to find a relation with the USLE methodology, soil losses were adjusted to $9 \%$ slope by experimentally derived factor corrections (Rejman et al., 1999). Thus, original data were multiplied by 1.03 for Czesławice and by 0.93 for Bogucin. Excluding snowmelt periods, corrected soil losses were presented in Table 3. For each year of studies, soil losses recorded in Czesławice were much smaller in comparison to Bogucin (on the average by 10 times). For the former site, especially large erosion was observed in 1994, and for the latter - in 1999 and 2007.

Soil erodibility, calculated as a ratio of soil losses to the erosivity index

TABLE 3. Corrected soil losses for non-winter periods (April-October) and experimentally derived soil erodibility

\begin{tabular}{|c|c|c|c|c|}
\hline \multirow{2}{*}{ Site } & \multirow{2}{*}{ Years } & \multirow{2}{*}{$\begin{array}{c}\text { No of measurement } \\
\text { periods }\end{array}$} & Soil losses & Soil erodibility \\
\hline & & & $\left(\mathrm{Mg} \cdot \mathrm{ha}^{-1}\right)$ & $\left(\mathrm{Mg} \cdot h a \cdot h \cdot \mathrm{MJ}^{-1} \cdot \mathrm{mm}^{-1} \cdot \mathrm{ha}^{-1}\right)$ \\
\hline \multirow{4}{*}{ Czesławice } & 1992 & 3 & 0.430 & 0.0008 \\
\hline & 1993 & 8 & 1.650 & 0.0053 \\
\hline & 1994 & 7 & 10.849 & 0.0122 \\
\hline & 1995 & 7 & 2.256 & 0.0034 \\
\hline \multirow{6}{*}{ Bogucin } & 1997 & 13 & 20.827 & 0.0214 \\
\hline & 1998 & 12 & 23.009 & 0.0243 \\
\hline & 1999 & 5 & 65.477 & 0.0554 \\
\hline & 2000 & 6 & 22.416 & 0.0614 \\
\hline & 2004 & 3 & 20.759 & 0.0598 \\
\hline & 2007 & 8 & 95.052 & 0.0675 \\
\hline
\end{tabular}


$\mathrm{EI}_{30}$ showed large annual variation for Czesławice and certain arrangement for Bogucin. For the former site, mean value of $\mathrm{K}$ factor was $0.0063 \mathrm{Mg} \cdot \mathrm{ha} \cdot \mathrm{h}$. $\cdot \mathrm{MJ}^{-1} \cdot \mathrm{mm}^{-1} \cdot \mathrm{ha}^{-1}$ (at cumulative soil losses $15.19 \mathrm{Mg} \cdot \mathrm{ha}^{-1}$ and $\mathrm{EI}_{30}$ index of 2394.0 MJ $\cdot \mathrm{mm} \cdot \mathrm{ha}^{-1} \cdot \mathrm{h}^{-1}$ ), for the latter - 0.0474 (soil losses - 247.54 Mg.ha ${ }^{-1}$, and $\left.\mathrm{EI}_{30}-5224.3 \mathrm{MJ} \cdot \mathrm{mm} \cdot \mathrm{ha}^{-1} \cdot \mathrm{h}^{-1}\right)$. During erosion studies in Bogucin, two periods with different values of soil erodibility are distinguished. In the years $1997-1998$, mean value was 0.0228 (with standard deviation of 0.0021$)$ and for the other 4 years $-0.0610(0.0050)$. Soil erodibility calculated from the equation [1] was 0.0795 and $0.0767 \mathrm{Mg} \cdot \mathrm{ha} \cdot \mathrm{h} \cdot \mathrm{MJ}^{-1}$. $\cdot \mathrm{mm}^{-1} \cdot \mathrm{ha}^{-1}$, respectively for Czesławice and Bogucin. However, in the case of soil which contain more than $70 \%$ of fine sand and silt fraction (as it is for the studied silt loam), Wischmeier and Smith (1978) recommend to use nomograph to determine the $\mathrm{K}$ factor. According to the latter method, soil erodibility is 0.0620 and $0.0598 \mathrm{Mg} \cdot \mathrm{ha} \cdot \mathrm{h} \cdot \mathrm{MJ}^{-1} \cdot \mathrm{mm}^{-1} \cdot \mathrm{ha}^{-1}$ for Czesławice and Bogucin.

Longer period of measurements on runoff plots enabled verification and better understanding of earlier results about applicability of the USLE (and soil erodibility factor) for erosion prediction on loess areas of Poland. Studies in Bogucin showed that soil erodibility of the similar range as predicted values from the USLE can be obtained after 2 years of maintaining runoff plots in fallow conditions. In the next years, the $\mathrm{K}$ values remained at obtained level, despite quite low of rainfall and runoff erosivity in the 2000 and 2004. It is in contrast to the earlier conclusions about soil erodibility based on initial period of studies (1997-1998) or analysis of singular events for the years 1997-2000 (Rejman et al. 1999; Rejman 2002). More than twice an increase of $\mathrm{K}$ factor in 1999 in comparison to 1998, can not be directly explained in terms of change of $\mathrm{EI}_{30}$ index, although total precipitation in 1999 was larger by $115 \mathrm{~mm}$. The increase of soil erodibility is well recognized by Wischmeier (1977), who link the change to some modification of soil properties and recommend start of measurements on runoff plots after two years period of maintaining plots under fallow conditions. Till now, the reasons of the change remain unidentified. Most probably, they cannot be connected with a decrease of total $\mathrm{C}$ organic content of soil. Such analyses were made in 1997 and repeated in 2004, and did not showed a significant drop of $\mathrm{C}$ organic on runoff-plots. In contrast to Bogucin site, 4-year period of studies in Czesławice was insufficient to obtain soil erodibility values similar to the prediction from the USLE. For sure, it was affected by main tillage performed in contour direction. Summarizing, both studies showed that level of soil erodibility is variable being dependent on certain still unrecognized soil property, being related to the status of soil culture achieved by cultivation system. Soils of similar experimental and predicted (from the USLE) values of $\mathrm{K}$ factor can be characterized as those that maintain in poor agricultural conditions (i.e. without organic manure applications). Such interpretation suggests that use of soil erodibility concept is valid for potential erosion risk assessment and can be applied in event-base models for soil prediction due to water erosion as SWAT (Neitsch et al. 2002) only for degraded 
or for soils with poor status of agricultural practices. For soils maintained under good practices (as it is still for Polish conditions), it provides to over estimation of soil losses.

\section{CONCLUSIONS}

Studies of erosion on runoff-plots of two sites of Lublin Upland showed that:

1. Soil erodibility derived from field experiments could reach similar values as those predicted from the USLE. Obtaining of similar level of measured and predicted $\mathrm{K}$ depended on tillage direction and time of maintaining plots under fallow conditions.

2. Under down-up slope plow, two years period of maintaining plots under fallow conditions was sufficient to get similar experimental and predicted values of soil erodibility. Under contour plow and during four years, soil erodibility derived experimentally showed large annual variation and was much lower than values predicted from the USLE.

3. Soil erodibility of the USLE can be used for development of potential risk assessment maps of water erosion. However, whilst reasons of instability of $\mathrm{K}$ factor remains still not recognized, use of soil erodibility approach in event-base models to predict erosion can be misleading.

\section{ACKNOWLEDGEMENT}

Part of the studies described in the paper was conducted under the project 0711/P01/ /2006/30 founded by Ministry of Science and Higher Education (coordinator: DSc. Ewa Smolska, Warsaw University). The financial support provided by this organization is gratefully acknowledged.

\section{REFERENCES}

BANASIK K., GÓRSKI D. 1993: Evaluation of rainfall erosivity for east Poland. In: Banasik K., Żbikowski A. [eds]. Runoff and sediment yield modelling. Warsaw Agricultural University Press, 129-134.

KLIMA K. 2002: Assessment of anti-erosion efficiency for three crop rotations applied to mountain soil. Electronic Journal of Polish Agricultural Universities, Environmental Development, 5(2), electronic version.

KIRKBY M.J.K., JONES R.J.A., IRVINE B., GOBIN A., GOVERS G., CERDAN O., VAN ROMPAEY A.J.J., LE BISSONNAIS I., DAROUSSIN J., KING D., MONTANARELLA L., GRIMM M., VIEILLEFONT V., PUIGDEFRABEGAS J., BOER M., KOSMAS C., YASSOGLOU N., TSARA M., MANTEL S., VAN LYNDEN G.J., HUTING J. 2004: Pan-European Soil Erosion Risk Assessment: The PESERA map v.1 October 2003. Special Publication Ispra No. 73, European Soil Buereau Research Report No 16, Office for Official Publications of the European Communities, Luxembourg, 1-18.

KORELESKI K. 1994: Amerykańskie systemy prognozowania erozji wodnej i wietrznej (Americans' systems of soil erosion predictions by water and wind). Roczniki Akademii Rolniczej w Poznaniu, 266, 341-347.

LICZNAR P. 2005: Artificial neural networks use for rainfall-runoff erosivity factor estimation. Electronic Journal of Polish Agricultural Universities, EnvironmentalDevelopment, 8(1), electronic version.

NEITSCH S.L., ARNOLD J.G., KINIRY J.R., WILLIAMS J.R., KING, K.W. 2002: Soil and water assessment tool. Theoretical documentation. Grassland, Soil and Water Research Laboratory. Agricultural Research Service. Temple, Texas, 1-506.

NIEMIEC J. 1998: Próba wyznaczenia wartości współczynnika K (podatność gleb na erozję) w zlewni górskiej w oparciu o metodę USLE (Attempt of determination of soil erodibility factor $\mathrm{K}$ for mountainous catchment on the basis of the USLE). Bibliotheca Fragmenta Agronomica, 4A/98, 81-92.

REJMAN J. 2002: Zastosowanie wartości progowych opadów w prognozowaniu erozji wodnej na stoku lessowym (Application of rainfall threshold values to water erosion prediction 
on loess slope). Zeszyty Problemowe Postępu Nauk Rolniczych, 487, 305-314.

REJMAN J., USOWICZ B., DĘBICKI R. 1999: Source of errors in predicting silt soil erodibility with USLE. Polish Journal of Soil Science, 32(1), 13-22.

REJMAN J., TURSKI R., PALUSZEK J. 1998: Spatial and temporal variations in erodibility of loess soil. Soil and Tillage Research, 46: 61-68.

RENARD K.G., FOSTER G.R., WEESIES G.A, MCCOOL D.K., YODER D.C. 1997: Predicting soil erosion by water - a guide to conservation planning with the Revised Universal Soil Loss Equation (RUSLE), Agricultural Handbook No 703. U.S. Gov. Print. Office, Washington, DC, $1-404$.

STASIK R., SZAFRAŃSKI C. 2001: Próba zastosowania modelu USLE do prognozowania intensywności erozji wodnej gleb Pojezierza Gnieźnieńskiego (Attempt of USLE application to water erosion prediction in Gniezno Lakeland). Folia Universitatis Agriculturae Stetinensis, 217: 213-216.

TURSKI R., SŁOWIŃSKA-JURKIEWICZ A., PALUSZEK J. 1987: Wpływ erozji na fizyczne właściwości gleb wytworzonych z lessu (Effect of erosion on physical properties of soils developed from loess). Roczniki Gleboznawcze, 22(1), 19-57.

VAN ROMPAEY A.J.J., VIEILLEFONT V., JONES R.J.A., MONTARELLA L., VERSTRAETEN G., BAZZOFFI P., DOSTAL T., KRASA J., DE VENTE J., POESEN J. 2003: Validation of soil erosion estimates at European scale. European Soil Bureau Research Report No 13, Office for official Publications of the European Communities, Luxembourg, 1-26.

WAWER R., NOWOCIEŃ E. 2007: Digital Map of Water Erosion Risk in Poland: A Qualitative, Vector-Based Approach. Polish Journal of Environmental Studies, 16(5), 763-772.

WISCHMEIER W.H. 1977: Use and misuse of the Universal Soil loss equation. In: Foster G.R. [ed.] Soil erosion: prediction and control. Soil Conservation Society of America, Ankeny, Iowa, 371-375.

WISCHMEIER W.H., SMITH D.D. 1978: Predicting rainfall erosion losses - a guide to conservation planning. Agricultural Handbook No 537, U.S. Department of Agriculture, Washington, D.C., 1-58.
Streszczenie: Zróżnicowanie wartości rocznych czynnika podatności na erozję gleby pylowej wytworzonej z lessu na podstawie 10-letnich badań poletkowych. Koncepcja podatności gleby na erozję, zaproponowana w modelu USLE i wiążąca zespół parametrów glebowych z czynnikiem erozyjności opadu i spływu powierzchniowego, znajduje zastosowanie w wielu modelach prognozujących erozję wodną. W pracy przedstawiono wyniki 10-letnich badań poletkowych prowadzonych na dwóch obiektach Wyżyny Lubelskiej. Pomimo podobnych warunków klimatycznych, badania wykazały duże zróżnicowanie podatności lessowej gleby pyłowej na erozję (czynnika $\mathrm{K}$ modelu USLE). Stwierdzono, że różnice te były związane z kierunkiem uprawy roli oraz czasem utrzymywania poletek w stanie czarnego ugoru. $\mathrm{Na}$ obiekcie z uprawą w poprzek spadku zbocza, 4-letni okres utrzymywania w czarnym ugorze poletek okazał się niewystarczający do osiagnięcia wartości $\mathrm{K}$ zbliżonych do wartości prognozowanych z USLE. Na obiekcie z uprawą wzdłuż spadku zbocza, wartości eksperymentalne zbliżone do prognozowanych uzyskano po dwóch latach i utrzymywały się one na podobnym poziomie przez następne 4 lata. Uzyskane wyniki dowiodły, że podatność gleby na erozję może być wykorzystana do wyznaczenia obszarów potencjalnego zagrożenia erozją wodną w Polsce, które odzwierciedlałyby rzeczywisty stan zagrożenia gleb pozostających w słabej kulturze rolnej. Brak rozpoznania przyczyn zróżnicowania podatności gleby na erozję w okresie do osiągnięcia jej stabilizacji ogranicza możliwość wykorzystania czynnika K w modelach symulujących pojedyncze zdarzenia erozyjne. Nieuwzględnienie w tych modelach aktualnej wartości podatności gleby na erozję prowadzi do przeszacowania prognozowanych wielkości erozji. Określenie czynników warunkujących zróżnicowanie podatności gleby na erozję wymaga dalszych badań.

\section{MS. received April 2008}

Authors' address:

Instytut Agrofizyki PAN

20-290 Lublin, ul. Doświadczalna 4

Poland

e-mail: rejman@demeter.ipan.lublin.pl 